\title{
An Islamic Code of Medical Ethics*
}

\author{
Hassan Gareebo, M.D.
}

Port Louis, Mauritius

DOI: http://dx.doi.org/10.5915/20-1-13053

The idea of instituting an Islamic code of medical ethics is praiseworthy and unique. In fact, no religious body has ever implemented such an idea before and it will undoubtedly prove very useful as guidelines for countries where Islam is the predominant religion. Right from the start, it should be understood that this code will be based exclusively on the Holy Qur'ān and Ahādîth. This Islamic Code of Medical Ethics should be adhered to by all Muslim doctors in the world.

The Islamic Code of Medical Ethics, in my judgement should include the following concepts.

\section{Motivation}

The allegiance of the doctor is primarily to his/her patients. The health of the patients should prime over all other considerations, i.e., their religion, nationality, race, color, creed, caste, politics or personal feelings. The physician should not be influenced by the motive of profit. The practice of medicine must never become a question of money. The only motive should be the cure/well being of the patient. The physician should maintain the utmost respect for human life and and human dignity. Allāh says:

"If any one saved a life, it would be as if he saved all humanity, if one takes a life, it is as if he killed all humanity.",

The Holy Prophet (PBUH) said:

"A Muslim should desire for his brother what he desires for himself,",

In another Hadith, the Holy Prophet (PBUH) said:

"The best of men is he who is most useful to mankind."'

2. Responsibility:

The responsibility of a doctor is tremendous because he is at all times dealing with people's lives, which are sacred. The doctor must honor this responsibility and the trust which the patient

Author's Address: 58 Sir Virgile Naz Street

Port Louis, Mauritius

*Original article published in Bulletin of Islamic Medicine, Kuwait, 1981; 1:625. puts in him. For this reason, a doctor owes to his patients complete loyalty and all the resources of his science. He has the responsibility of putting in the maximum effort in all aspects of health care to achieve the optimum result for his patients. Allāh says

"O you who believe, betray not the trust of Allāh and the Apostle." 4

"You who believe, fulfill all obligtions."'s

3. Knowledge:

A doctor must at all times continue to perfect himself in the science and art of medicine. Continued medical education should form part of the daily curriculum of a doctor. It is one of the means whereby a doctor can sincerely feel that he is doing the best he can for a patient. Allāh says in the Qur'än:

"O my Lord advance me in knowledge." "Wisdom is knowledge and is a great wealth.""

4. Temperament:

A doctor must always be kind, gentle and generous to his patients. He should always behave correctly towards his patients. He should show compassion to his patients when the occasion demands. This will create an atmosphere of confidence, relaxation and trust in the company of patients and this is conductive to the practice of good medicine. Islam preaches kindness and generosity on the part of Muslims at all times. Allāh says in the Qur'ān:

"It is part of the mercy of Allāh that thou dost deal gently with them."

"Always say a word directed to the right.""

5. Humility:

A doctor must be humble because he knows that his knowledge of medicine is always imperfect and inadequate. This humility will permit him to learn from others even from junior colleagues. The Qur'ān teaches us humility in all spheres of life. "And the servants of Alläh are those who walk on the earth in humility.",

6. Acknowledgement that Allăh is the Curor (alShāfī): 
A doctor must at all times offer hope to his patients. He must always try to relieve the suffering of his patients, be it physical or mental. He must never harm a patient, even during an attempt to treat his disease. However, a Muslim physician should always acknowledge that despite his best efforts, the results are ordained by Allah. The physician cannot always "cure" his/her patients, Allāh is the Curor (al-Shãfi). Allāh says in the Qur'ān:

"If Allāh do touch thee with hurt, there is none that can remove it but $\mathrm{He}$, if $\mathrm{He}$ designs some benefit for thee, none can keep back His favor. $\mathrm{He}$ causeth it to reach whomsoever of His servants $\mathrm{He}$ pleaseth...." "म

'A'ishah said:

"'Whenever Allāh's apostle (PBUH) paid visit to a patient or a patient was brought to him, he used to invoke Allāh, saying take away the disease, $\mathrm{O}$ the Lord of the people. Cure him as You (Allāh) are the one who cures. There is no cure but Yours, a cure that leaves no disease." 12

7. Priviledged position:

A doctor must not use his priviledged position for any form of personal gain, e.g., in a business transaction with his patients, etc.

\section{Confidentiality:}

A doctor must not divulge any of the personal information he/she comes to know about the patients. Because of the confidence entrusted him, confidentiality is a must. The Holy Prophet (PBUH) said:

"A confidence given is a trust:", 13

The Qur'ān has strict rules about the principle of trust.

"Allāh doth command you to render back your trust to those to whom they are due...."

\section{Emotional involvement:}

A doctor must not become romantically involved with a patient. The doctor must at all times restrain physical and emotional feelings evoked by patients. Should a physician fail in this or should a patient become physically attracted to the physician, it is the duty of the physician to delegate the care of this patient to a colleague.

\section{Abortion:}

Abortion is prohibited. An exception is the therapeutic abortion if it is the only way to save the mother's life. Allāh says in the Qur'ān:

"... kill not your children for fear of want. We shall provide sustenance for you and for them...", is

However, this particular verse is probably more relevant to infanticide than to abortion.

\section{Contraception:}

The assumption that the world can produce enough to feed every mouth is incorrect because of the limited world food supplies and the unequal distribution of wealth. Therefore contraception should be encouraged by doctors, if advice is sought by patients.

Some early Muslims questioned the Holy Prophet $(\mathrm{PBUH})$ concerning contraception by the method then practiced - 'Azl i.e. coitus interuptus. $\mathrm{He}(\mathrm{PBUH})$ replied:

"Do you do this? If Allāh has decreed that a child is to be born, nothing can prevent it."

This and several other ahadith indicate that 'azl was practiced and was not prohibited by the Prophet.

12. Euthansia is unlawful:

The Qur'an says:

"... Nor take the life which Alläh has made sacred except for just cause..." "17

However, in an attempt to relieve the suffering of a patient who is dying of a fatal disease, the doctor may unwillingly help the patient on his way to his death. In this particular case, I believe that the doctor is not committing euthanasia but is observing one of the basic rules of medical ethics i.e. relieve the suffering of his patients.*

\section{Exorcism:}

Appeal to Allāh to remove someone's illness is not prohibited but having recourse to evil practices is definitely prohibited. Bad omens and superstitious beliefs are unlawful and were greatly condemned by the Holy Prophet (PBUH).

\section{Teaching:}

A doctor must always be ready to teach his junior colleagues and students in Medicine everything he knows and must not hide any special knowledge or special formula of drugs or special technique in surgery. The best embodiment of this principle is the life of the Holy Prophet Muhammad (PBUH) who devoted his entire life to teaching mankind the righteous path.

15. Medical Research:

Research that has as its objective, the progress of

\section{*Editor's note:}

These views are the author's and do not necessarily reflect those of the editor's or of I.M.A. Inshallah we plan to publish more detailed discussion of these topics in future issues. 
medical science, is greatly encouraged. It falls under the great recommendation for quest for knowledge. Clinical research may be carried out by doctors if they observe the following principles:

a. Clinical research is ethical only if the doctor performing it is ready to include among his patients in the clinical trial his closest relatives e.g. his wife, children, parents, etc.

b. Clinical research should be carried out by scientifically qualified persons.

c. Patients included in clinical research must be made aware of all the facts involved in the research and should give their consent if of age and of sound mind, otherwise their guardians could give their consent.

d. The right of a patient of withdraw from a clinical research program must be respected.

16. Withholding information from the patient:

Generally it is the duty of a physician to tell the patient all pertinent facts. However, it is permissible under certain circumstances to withhold information from a patient who suffers from a fatal disease like cancer. Even lying to such a patient is not a sin. However, the closest relatives must be made aware of the nature of the illness. The patient must be told if he demands to know at all cost and the doctor deems that this knowledge will not unduly harm him.

\section{Convassing:}

A doctor must refrain from any form of self advertising or convassing. Some degree of advertising is necessary for a doctor who has just started a practice in a certain locality but it has to be discreet and humble.

18. Certification:

Certification by a doctor must always be truthful: He should personally verify what he is going to certify.

19. Sincerity (common good):

Doctors must always work for the common good; even if it means that it is detrimental to his personal gain. For example, doctors must always work towards prevention of disease although this will result in a reduction of his clientele. This in fact is basically a form of charity and unselfishness. Abü Hurayrah (Allāh be pleased with him) reported that Holy Prophet (PBUH) said:

"Removal from the way of that which is harmful is charity." "8
20. Use of forbidden articles:

A doctor may at certain times use drugs or materials which are forbidden. For example, intoxicants may be used as sedatives, analgesics, anesthetics, etc. Similarly under certain circumstances, that is to save the life of a patient, the use of a pork valve xenograft is permitted.*

21. Behavior towards colleagues:

A doctor should behave towards colleagues as he/she would like them to behave towards him/her. Doctors should keep good relations among themselves. A doctor should refrain from speaking adversely of other colleagues. The Holy Prophet (PBUH) said:

"Do not hate one another and do not be jealous of one another and do not boycott one another and be servants of Allāh as brothers. It is unlawful that one should sever his relations with his brother for more than three days." 19

22. Practice what you preach:

A doctor must observe in private and public life what he preaches to his patients for their well being e.g. avoidance of alcohol, cigarettes, intoxicants, etc., and observance of moderation in eating habits, regular excercise, etc.

23. General behavior:

The personal and public life of a doctor must be beyond reproach. He should not engage in any activity incompatible with the dignity of his profession.

Here a doctor must submit himself to the general principles of behavior as preached by Islam. The Holy Prophet (PBUH) said:

"The best among you are those who have the best manners and character.",20

In another hadith, the Holy Prophet (PBUH) said:

"The one who looks after widows and the poor ones is like the one who struggles in the way of Allah or the one who keeps awake in the night for prayers and fasts during the day.", 21

The nature of this paper does not permit any summary to be made or conclusion to be drawn, but it is my hearfelt desire that an Islamic Code

*Editor's note:

With regard to the use of forbidden articles as a treatment modality, this would be allowed if no substitute is available and the treatment s considered necessary. However, according to our knowledge today substitutes are available to alcohol and pork products eliminating the necessity for use of forbiden articles in most cases. 
of Medical Ethics be set afoot and an Islamic Medical Council be established to promulgate these principles.

\section{Rereferences}

1. Glorious Qur'ān, Chapter 5, verse 32

2. Sahìh al-Bukhāri, Division 2, Book of Faith, Chapter 7, vol 1, p 19, M.M. Khan, Editor, Dar al-'Arabiah, Publishing, Printing and distribution, Beirut, Lebanon.

3. Ibn Mājah (Arabic), Book of Marriage, number 50, Muhammad Fu'ād 'Abdul Bāqi, editor, 'Isā al-Bã̉bi al-Halabi publishing Company, Cairo, Egypt.

4. Glorious Qur'ān, Chapter 8, verse 27

5. Glorious Qur'ān, Chapter 5, verse 1

6. Glorious Qur'ān, Chapter 20, verse 114

7. Glorious Qur'ān, Chapter 11, verse 269

8. Glorious Qur'ān, Chapter 3, verse 159

9. Glorious Qur'ān, Chapter 33, verse 70

10. Glorious Qur'ān, Chapter 25, verse 63

11. Glorious Qur'ān, Chapter 10, verse 107

12. Sahīh al-Bukhāri Division 70, Book of Patients, Chapter 20, vol 7, p 392.

13. Sunan Abū Dāwūd (Arabic), Book of Judgement, Chapter 32, 'Izzat al-Da "ās and 'Adil al-
Sayyid, editors, Published by Muhammad 'Ali al-Sayyid, Hims, Syria, 1972.

14. Glorious Qur'än, Chapter 4, verse 58

15. Glorious Qur'ān, Chapter 6, verse 151

16. Sahìh al-Bukhäri, Division 62, Book of Wedlock, Chapter 97, vol 7, p 102, M.M. Khan, editor, Dar al-'Arabiah, Publishing, Printing and Distribution, Beirut, Lebanon.

17. Glorious Qur'ān, Chapter 6, verse 151

18. Sahỉh al-Bukhāri, Division 43, Book of Oppressions, Chapter 25, vol 3, p 386, M.M. Khan, editor, Dar al-'Arabiah, Publishing, Printing and Distribution, Beirut, Lebanon.

19. Sahih al-Bukhāri, Division 73, Book of Manners, Chapter 57, vol 8, p 58, M.M. Khan, editor, Dar al-'Arabiah, Publishing, Printing and Distribution, Beirut, Lebanon.

20. Sahih al-Bukhäri, Division 73, Book of Manners, Chapter 38, vol 8, p 35, M.M. Khan, editor, Dar al-'Arabiah, Publishing, Printing and Distribution, Beirut, Lebanon.

21. Sahih al-Bukhäri, Division 64, Book of Provision, Chapter 1, vol 7, p 202, M.M. Khan, editor, Dar al-'Arabiah, Publishing, Printing and Distribution, Beirut, Lebanon. 